\author{
M.Z. Akkad, T. Bányai, Miskolc, Hungary
}

\title{
ANALYSIS AND COMPARISON OF THE WASTE MANAGEMENT DEVELOPMENT IN HUNGARY AND SLOVAKIA
}

\begin{abstract}
Waste production is an indispensable human process that happens daily in all communities. With the population increase and the industry developments, the waste amounts are growing, and their treating processes are taking a bigger share of the transportation and handling tasks in the city logistics. These waste collection, transportation, and treatment are described as waste management has been investigated and developed especially with the various application, solutions, and developments in the logistics, transportation, and industrial areas. Also, with the higher attention to the environmental impact in the different areas, the green aspect of waste management takes more importance particularly in city logistics where congestion occurs regularly. Within this work, waste management is analyzed in Europe generally and Hungary specifically. Eurostat database is used for that purpose next to previous research work tackling this topic. Also, a comparison between the waste management operations in Hungary and Slovakia is discussed to show the difference of these operations' developments between the two countries between 2014 and 2020.
\end{abstract}

Keywords: waste management; city logistics; data analysis.

\section{INTRODUCTION}

The European Union repeatedly formulated aims, plans, and recommendations concerning waste management [1]. A common EU aim is to recycle $65 \%$ of municipal waste and $75 \%$ of packaging waste by 2030 [2]. The document of "General Union Environment Action Program to 2020; Living well, within the limits of our planet" described a waste management hierarchy according to environmental aspects $[1,3]$ :

- Prevention,

- reduce waste. To avoid any extra amount of waste,

- reuse. It requires relatively little or no processing where the material can be used again without any structural changes in it,

- recycling, and waste treatment. It means creating usable raw materials from the waste,

- incineration with energy recovery. The released gases and heat are used for power generating. By the end of this process, the gases are released after purification from any contaminated substances,

- another recovery, and disposal. this method remains the worst option that should be avoided as much as possible for its long-time need.

It is possible to describe waste management as the collective process of monitoring, collecting, transporting, treating, recycling, or disposing of waste. 
This process takes its importance to lighten the negative effects of waste on the health, environment, and public appearance. Waste can be defined as any excess undesirable material, and it can mean rubbish or trash. Waste collection is a main part of the waste management process. It is the process of transferring the waste to the treatment or landfill facility. Waste treatment refers to the needed processes to ensure that waste has the least possible effect on the environment. The waste treatment methods may vary from a country to another [4]. On one hand, waste management may be considered as a necessary cost that should be paid to reach a clean environment that is not harmful to the health of inhabitants. On the other hand, other authorities give great importance to waste management because it saves raw materials resources. Many developed countries implemented successfully waste treatment projects to get benefits from waste like recycling.

\section{WASTE MANAGEMENT DEVELOPMENT}

It is observed that there is a shift towards a more holistic approach in the analysis of waste management [5], and reducing environmental impact is the priority for future generations. Waste minimization mechanisms should be implemented as well, taking into consideration the sustainable development principles [6]. Also, sustainable development implementation mustn't cause longterm business disadvantages for companies [7]. Numerous European cities have been using sustainable systems in waste management for a few years, working on optimizing the generated and collected amounts of waste to a minimum. However, the dominant method of waste disposal is landfilling in Hungary [1]. The waste minimization techniques can be used in the waste reduction of municipal waste treatment, but the waste management problem in the European Union is classified by [8]:

- the increase in industrialization and urbanization,

- the increase in the generated waste amount per capita,

- the maintain need of a high level of infrastructure investment (incinerators, landfills, recycling facilities),

- institutional barriers,

- the diversity of interest groups next to the political and legal changes in the field of waste management.

Different waste collection solutions are analyzed in the literature focusing on different aspects of evaluation, like technology, logistics, human resources, policies, and social aspects [9]. The optimal structure of the waste collection system influences the performance of waste collection processes. A Portugal case study shows that strategic expansion plans of waste management companies can be supported by complex mathematical models and heuristic optimization algorithms [10]. The importance of multi-level solutions is highlighted with a three-phase 
hierarchical approach in the Spanish region of Galicia [11] and Ankara [12]. the authors focused on routing problems and facility location. Waste collection systems show a broad range of uncertainties, for instance, the design of appropriate infrastructure difficulties for waste collection and recycling were described in a Hong Kong case study [13]. Other case studies from Denmark [14], Kampala City [15], Italy [16], and Taiwan [17] demonstrated the importance of new technologies in municipal waste collection systems.

\section{ANALYSIS OF WASTE MANAGEMENT DATA IN EUROPE AND HUNGARY}

The used dataset in this chapter was imported from the Eurostat Statistics website, the statistical office of the European Union. Two data were used to be analyzed. The municipal waste management operations [18] and the recycling rate of municipal waste [19]. It should be considered that the collected dataset was based on the municipal waste which is produced by households next to other waste sources like commerce, offices, and public institutions. The generated municipal waste amount data includes the collected waste by or on behalf of municipal authorities and disposed of through the responsible waste management system. According to the OECD/Eurostat Joint Questionnaire municipal [18], waste includes the following materials groups: paper, paperboard and paper products, plastics, glass, metals, food and garden waste, and textiles. As it includes other types of waste such as bulky waste, households, commerce and trade, small businesses, office buildings, and institutions. As well as the collected waste from selected municipal services, for instance, waste from garden and park maintenance, waste from street cleaning services. However, it does not include waste from municipal sewage network and treatment, municipal construction, and demolition waste. The recycling rate of municipal waste indicates how waste from final consumers is used as a resource in the circular economy [19]. The municipal waste recycling rate gives a useful indication of the overall waste management system quality. The Recycling rate indicator measures the share of recycled municipal waste in the total municipal waste generation. Recycling includes material recycling, composting, and anaerobic digestion. The ratio is expressed in percent (\%) as both terms are measured in the same unit, namely tons. The following definitions were introduced within the collected data:

- Incineration expresses thermal treatment of waste in an incineration plant,

- Energy recovery is defined as the incineration that fulfills the energy efficiency criteria,

- Recycling means any recovery operation which waste materials are reprocessed into products, materials, or substances whether for the original or other purposes, 
- Composting and anaerobic digestion are processes of biological decomposition of biodegradable waste under controlled aerobic (composting) or anaerobic conditions,

- Landfill is defined as the deposit of waste into or onto land; it includes specially engineered landfills and temporary storage of over one year on permanent sites.

The first table shows the annual waste generated in thousands of tons for 37 European countries from 2014 to 2020 . It is interesting to see that the waste amount in Hungary is relatively the same except for 2020 where it is $6.5 \%$ less than the average of 2014-2019.

Table 1 - annual municipal waste generated in thousands of tons [18]

\begin{tabular}{|l|c|c|c|c|c|c|c|}
\hline & 2014 & 2015 & 2016 & 2017 & 2018 & 2019 & 2020 \\
\hline Albania & 1,229 & 1,413 & 1,300 & 1,254 & 1,325 & 1,087 & 1,048 \\
\hline Austria & 4,833 & 4,836 & 4,928 & 5,018 & 5,119 & 5,220 & $:$ \\
\hline Belgium & 4,762 & 4,643 & 4,746 & 4,672 & 4,677 & 4,779 & 4,800 \\
\hline $\begin{array}{l}\text { Bosnia and } \\
\text { Herzegovina }\end{array}$ & 1,335 & 1,249 & 1,244 & 1,235 & 1,244 & 1,228 & $:$ \\
\hline Bulgaria & 3,192 & 3,011 & 2,881 & 3,080 & 2,862 & $:$ & $:$ \\
\hline Croatia & 1,637 & 1,654 & 1,680 & 1,716 & 1,768 & 1,812 & 1,693 \\
\hline Cyprus & 513 & 525 & 539 & 537 & 562 & 571 & 543 \\
\hline Czechia & 3,261 & 3,337 & 3,580 & 5,177 & 5,248 & 5,338 & 5,419 \\
\hline Denmark & 4,558 & 4,671 & 4,757 & 4,728 & 4,715 & 4,907 & 4,927 \\
\hline Estonia & 470 & 473 & 494 & 514 & 535 & 490 & $:$ \\
\hline Finland & 2,630 & 2,738 & 2,768 & 2,812 & 3,041 & 3,123 & 3,296 \\
\hline France & 34,260 & 34,344 & 35,356 & 35,817 & 35,889 & 37,397 & 36,154 \\
\hline Germany & 51,102 & 51,625 & 52,133 & 51,790 & 50,260 & 50,612 & 52,567 \\
\hline Greece & 5,315 & 5,277 & 5,367 & 5,415 & 5,523 & 5,613 & $:$ \\
\hline Hungary & 3,795 & 3,712 & 3,721 & 3,768 & 3,729 & 3,780 & 3,545 \\
\hline Iceland & 175 & 195 & 220 & 225 & 247 & $:$ & $:$ \\
\hline Ireland & 2,619 & $:$ & 2,763 & 2,768 & 2,912 & 3,086 & 2,768 \\
\hline Italy & 29,652 & 29,524 & 30,112 & 29,572 & 30,165 & 30,023 & $:$ \\
\hline Latvia & 726 & 798 & 802 & 798 & 785 & 840 & 909 \\
\hline Lithuania & 1,270 & 1,300 & 1,272 & 1,286 & 1,301 & 1,319 & 1,350 \\
\hline Luxembourg & 348 & 346 & 474 & 476 & 488 & 491 & 498 \\
\hline Malta & 273 & 285 & 292 & 312 & 326 & 351 & 332 \\
\hline Montenegro & 298 & 310 & 307 & 305 & 321 & 339 & 302 \\
\hline Netherlands & 8,894 & 8,866 & 8,861 & 8,792 & 8,806 & 8,806 & 9,321 \\
\hline North Macedonia & 765 & 786 & $:$ & $:$ & 855 & 916 & 913 \\
\hline Norway & 2,175 & 2,187 & 3,946 & 3,949 & 3,927 & 4,151 & 3,905 \\
\hline Poland & 10,330 & 10,863 & 11,654 & 11,969 & 12,485 & 12,753 & 13,117 \\
\hline Portugal & 4,710 & 4,769 & 4,891 & 5,007 & 5,213 & 5,281 & 5,279 \\
\hline & & & 25 & & & & \\
\hline
\end{tabular}


ISSN 2078-7405 Cutting \& Tools in Technological System, 2022, Edition 96

\begin{tabular}{|l|c|c|c|c|c|c|c|}
\hline Romania & 4,956 & 4,904 & 5,143 & 5,333 & 5,296 & 5,430 & 5,534 \\
\hline Serbia & 2,130 & 1,840 & 1,890 & 2,150 & 2,230 & 2,350 & $:$ \\
\hline Slovakia & 1,733 & 1,784 & 1,890 & 2,058 & 2,254 & 2,299 & 2,366 \\
\hline Slovenia & 892 & 926 & 943 & 974 & 1,009 & 0 & 1,024 \\
\hline Spain & 20,836 & 21,158 & 21,542 & 22,018 & 22,229 & 22,262 & 21,529 \\
\hline Sweden & 4,295 & 4,422 & 4,439 & 4,551 & 4,416 & 4,611 & 4,460 \\
\hline Switzerland & 6,006 & 6,030 & 6,050 & 5,992 & 6,012 & 6,079 & 6,096 \\
\hline Turkey & 31,230 & 31,283 & 33,763 & 34,173 & 34,533 & 35,017 & $:$ \\
\hline United Kingdom & 31,129 & 31,475 & 31,710 & 30,912 & 30,786 & $:$ & $:$ \\
\hline
\end{tabular}

The second table shows the annual waste generated in kilograms per capita for the same 37 European countries as it would be easier to compare the numbers in this case. In 2014, Hungary is $24^{\text {th }}$ in the order, while it is the $33^{\text {rd }}$ in 2018 , which means a waste amount decrease, and that is harmonious with the previous table.

Table 2 - annual municipal waste generated in kilograms per capita [18]

\begin{tabular}{|l|c|c|c|c|c|c|c|}
\hline & 2014 & 2015 & 2016 & 2017 & 2018 & 2019 & 2020 \\
\hline Albania & 425 & 491 & 452 & 436 & 462 & 381 & 369 \\
\hline Austria & 565 & 560 & 564 & 570 & 579 & 588 & $:$ \\
\hline Belgium and & 425 & 412 & 419 & 411 & 409 & 416 & 416 \\
\hline $\begin{array}{l}\text { Bosnia } \\
\text { Herzegovina }\end{array}$ & 349 & 340 & 354 & 352 & 356 & 352 & $:$ \\
\hline Bulgaria & 442 & 419 & 404 & 435 & 407 & $:$ & $:$ \\
\hline Croatia & 387 & 393 & 403 & 416 & 432 & 445 & 418 \\
\hline Cyprus & 602 & 620 & 633 & 625 & 646 & 648 & 609 \\
\hline Czechia & 310 & 316 & 339 & 489 & 494 & 500 & 507 \\
\hline Denmark & 808 & 822 & 830 & 820 & 814 & 844 & 845 \\
\hline Estonia & 357 & 359 & 376 & 390 & 405 & 369 & $:$ \\
\hline Finland & 482 & 500 & 504 & 510 & 551 & 566 & 596 \\
\hline France & 517 & 516 & 530 & 535 & 535 & 556 & 537 \\
\hline Germany & 631 & 632 & 633 & 627 & 606 & 609 & 632 \\
\hline Greece & 488 & 488 & 498 & 504 & 515 & 524 & $:$ \\
\hline Hungary & 385 & 377 & 379 & 385 & 381 & 387 & 364 \\
\hline Iceland & 535 & 588 & 655 & 656 & 702 & $:$ & $:$ \\
\hline Ireland & 562 & $:$ & 581 & 576 & 598 & 625 & 555 \\
\hline Italy & 488 & 486 & 497 & 488 & 499 & 503 & $:$ \\
\hline Latvia & 364 & 404 & 410 & 411 & 407 & 439 & 478 \\
\hline Lithuania & 433 & 448 & 444 & 455 & 464 & 472 & 483 \\
\hline Luxembourg & 626 & 607 & 815 & 798 & 803 & 791 & 790 \\
\hline Malta & 628 & 641 & 642 & 666 & 672 & 697 & 643 \\
\hline Montenegro & 479 & 498 & 493 & 490 & 516 & 545 & 486 \\
\hline
\end{tabular}


ISSN 2078-7405 Cutting \& Tools in Technological System, 2022, Edition 96

\begin{tabular}{|l|c|c|c|c|c|c|c|}
\hline Netherlands & 527 & 523 & 520 & 513 & 511 & 508 & 534 \\
\hline North Macedonia & 370 & 380 & $:$ & $:$ & 412 & 441 & 441 \\
\hline Norway & 423 & 422 & 754 & 748 & 739 & 776 & 726 \\
\hline Poland & 272 & 286 & 307 & 315 & 329 & 336 & 346 \\
\hline Portugal & 453 & 460 & 474 & 486 & 507 & 513 & 513 \\
\hline Romania & 249 & 247 & 261 & 272 & 272 & 280 & 287 \\
\hline Serbia & 299 & 259 & 268 & 306 & 319 & 338 & $:$ \\
\hline Slovakia & 320 & 329 & 348 & 378 & 414 & 421 & 433 \\
\hline Slovenia & 432 & 449 & 457 & 471 & 486 & 0 & 487 \\
\hline Spain & 448 & 456 & 463 & 473 & 475 & 472 & 455 \\
\hline Sweden & 443 & 451 & 447 & 452 & 434 & 449 & 431 \\
\hline Switzerland & 733 & 728 & 723 & 709 & 706 & 709 & 706 \\
\hline Turkey & 405 & 400 & 426 & 425 & 424 & 424 & $:$ \\
\hline United Kingdom & 482 & 483 & 483 & 468 & 463 & $:$ & $:$ \\
\hline
\end{tabular}

The second table shows the recycling rate of municipal waste as a percentage for 36 European countries. Unfortunately, it shows that Hungary has a very slight rise in the recycling rate between 2014 and 2020 while taking into consideration that the maximum rate was in 2018. By analyzing the data, it is very interesting to notice that Slovakia has a big raise from $10.3 \%$ to $42.2 \%$ in 2020 . Considering the similar geographical location and relatively the country area, a comparison of the waste management methods between Hungary and Slovakia is presented in next chapter.

Table 3 - annual recycling rate of municipal waste as a percentage [19]

\begin{tabular}{|l|c|c|c|c|c|c|c|}
\hline & 2014 & 2015 & 2016 & 2017 & 2018 & 2019 & 2020 \\
\hline Austria & 56.3 & 56.9 & 57.6 & 57.7 & 57.7 & 58.2 & $:$ \\
\hline Belgium & 53.8 & 53.5 & 53.5 & 53.9 & 54.4 & 54.7 & 54.2 \\
\hline Bulgaria & 23.1 & 29.4 & 31.8 & 34.6 & 31.5 & $:$ & $:$ \\
\hline Croatia & 16.5 & 18.0 & 21.0 & 23.6 & 25.3 & 30.2 & 34.3 \\
\hline Cyprus & 14.8 & 16.6 & 16.1 & 16.2 & 16.5 & 16.3 & 16.4 \\
\hline Czechia & 25.4 & 29.7 & 33.6 & 32.0 & 32.2 & 33.3 & 33.8 \\
\hline Denmark & 45.4 & 47.4 & 48.3 & 47.6 & 49.9 & 51.5 & 53.9 \\
\hline Estonia & 31.3 & 28.3 & 28.1 & 28.4 & 28.0 & 30.8 & $:$ \\
\hline Finland & 32.5 & 40.6 & 42.0 & 40.5 & 42.3 & 43.5 & 41.6 \\
\hline France & 39.7 & 40.7 & 42.9 & 44.1 & 45.1 & 43.9 & 42.2 \\
\hline Germany & 65.6 & 66.7 & 67.1 & 67.2 & 67.1 & 66.7 & 67.0 \\
\hline Greece & 15.4 & 15.8 & 17.2 & 18.9 & 20.1 & 21.0 & $:$ \\
\hline Hungary & 30.5 & 32.2 & 34.7 & 35.0 & 37.4 & 35.9 & 33.0 \\
\hline Iceland & 29.7 & 0.0 & 0.0 & 0.0 & 0.0 & $:$ & $:$ \\
\hline Ireland & 39.8 & $:$ & 40.7 & 40.4 & 37.6 & 37.4 & 40.4 \\
\hline Italy & 41.6 & 44.3 & 45.9 & 47.8 & 49.8 & 51.4 & $:$ \\
\hline
\end{tabular}


ISSN 2078-7405 Cutting \& Tools in Technological System, 2022, Edition 96

\begin{tabular}{|l|c|c|c|c|c|c|c|}
\hline Latvia & 27.0 & 28.7 & 25.2 & 24.8 & 25.2 & 41.0 & 39.6 \\
\hline Lithuania & 30.5 & 33.1 & 48.0 & 48.1 & 52.5 & 49.7 & 45.1 \\
\hline Luxembourg & 47.7 & 47.4 & 49.2 & 48.7 & 49.0 & 48.9 & 52.8 \\
\hline Malta & 11.7 & 10.9 & 12.7 & 11.5 & 10.4 & 9.1 & 10.5 \\
\hline Montenegro & $:$ & $:$ & $:$ & $:$ & 3.4 & 5.0 & 4.6 \\
\hline Netherlands & 50.9 & 51.8 & 53.5 & 54.6 & 55.9 & 56.9 & 56.8 \\
\hline Norway & 42.2 & 42.8 & 38.2 & 38.8 & 40.7 & 40.9 & 44.9 \\
\hline Poland & 26.5 & 32.5 & 34.8 & 33.8 & 34.3 & 34.1 & 38.7 \\
\hline Portugal & 30.4 & 29.8 & 30.9 & 29.1 & 29.1 & 28.9 & 26.5 \\
\hline Romania & 13.1 & 13.2 & 13.4 & 14.0 & 11.1 & 11.5 & 13.7 \\
\hline Serbia & 0.7 & 0.8 & 0.3 & 0.3 & 0.3 & $:$ & $:$ \\
\hline Slovakia & 10.3 & 14.9 & 23.0 & 29.8 & 36.3 & 38.5 & 42.2 \\
\hline Slovenia & 36.0 & 54.1 & 55.6 & 57.8 & 58.9 & $:$ & 59.3 \\
\hline Spain & 30.8 & 30.0 & 33.9 & 36.1 & 34.8 & 39.3 & 36.4 \\
\hline Sweden & 49.3 & 47.5 & 48.4 & 46.8 & 45.8 & 46.6 & 38.3 \\
\hline Switzerland & 53.5 & 52.7 & 52.5 & 52.5 & 52.5 & 53.0 & 52.8 \\
\hline Turkey & $:$ & $:$ & 9.2 & 9.2 & 11.5 & 11.5 & $:$ \\
\hline United Kingdom & 43.4 & 43.3 & 44.0 & 43.8 & 44.1 & $:$ & $:$ \\
\hline
\end{tabular}

\section{HUNGARY AND SLOVAKIA DATA COMPARISON}

Tables 4 and 5 show the municipal waste management operations in Hungary and Slovakia respectively.

Table 4 - annual municipal waste generated in thousands of tons for Hungary [18]

\begin{tabular}{|l|c|c|c|c|c|c|c|}
\hline & 2014 & 2015 & 2016 & 2017 & 2018 & 2019 & 2020 \\
\hline $\begin{array}{l}\text { Incineration with energy } \\
\text { recovery }\end{array}$ & 373 & 525 & 554 & 608 & 501 & 515 & 604 \\
\hline Landfill and other disposal & 2,181 & 1,991 & 1,888 & 1,825 & 1,851 & 1,918 & 1,770 \\
\hline Incineration & 0 & 0 & 0 & 0 & 0 & 0 & 4 \\
\hline Recycling (material) & 923 & 963 & 998 & 1,010 & 1,085 & 1,005 & 788 \\
\hline $\begin{array}{r}\text { Recycling (composting } \\
\text { and digestion) }\end{array}$ & 236 & 231 & 294 & 309 & 309 & 353 & 383 \\
\hline
\end{tabular}

Table 5 - annual municipal waste generated in thousands of tons for Slovakia [18]

\begin{tabular}{|l|c|c|c|c|c|c|c|}
\hline & 2014 & 2015 & 2016 & 2017 & 2018 & 2019 & 2020 \\
\hline Incineration with energy recovery & 190 & 191 & 197 & 197 & 187 & 211 & 188 \\
\hline Landfill and other disposal & 1,158 & 1,226 & 1,236 & 1,246 & 1,248 & 1,197 & 1,175 \\
\hline Incineration & 4 & 0 & 0 & 0 & 30 & 85 & 0 \\
\hline Recycling (material) & 88 & 136 & 291 & 433 & 603 & 616 & 675 \\
\hline $\begin{array}{l}\text { Recycling (composting and } \\
\text { digestion) }\end{array}$ & 91 & 130 & 143 & 181 & 215 & 269 & 324 \\
\hline
\end{tabular}


Figures 1 and 2 show the visualization of the waste management operations for Hungary and Slovakia respectively. Energy recovery refers to incineration with energy recovery, A refers to material, and B refers to composting and digestion.

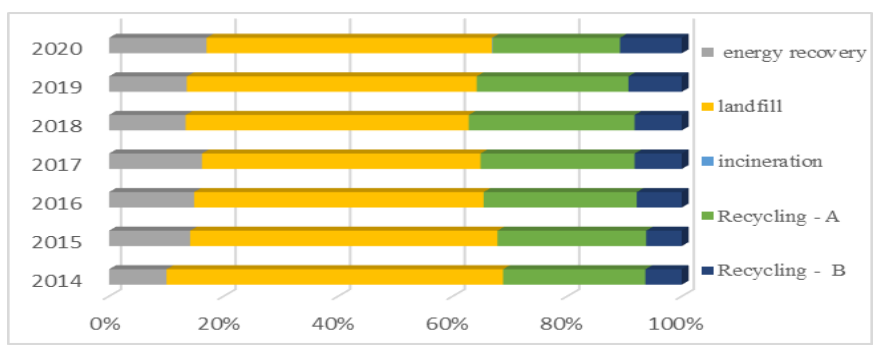

Figure 1 - Waste management operations in Hungary

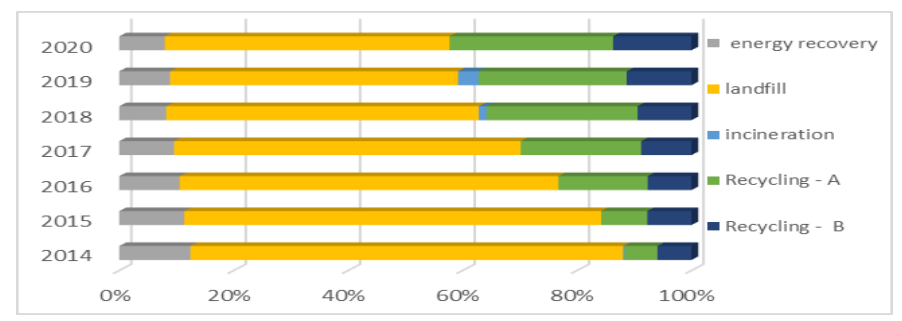

Figure 2 - Waste management operations in Slovakia

While in Hungary, it does not show any main changes in the waste management operations with a slight decrease in the landfilling, Slovakia shows a big increase in the recycling process especially for the material recycling on the share of landfilling mainly. This reflects the green efforts into a more sustainable waste management system in Slovakia in the last few years. However, the recycling rate in Hungary was three doubles than Slovakia in 2014. This shows a big importance to analyze deeply the used methods in both countries in the last decade since it has promising possibility that this study can be used and reflected on the waste management system positively in Hungary, Slovakia, or both.

\section{SUMMARY}

Taking the importance of the waste management systems that have direct effect on the environmental, social, and sustainability aspects, this work provided an analysis of the annual municipal waste amount, the annual municipal waste generated in kilograms per capita, and the annual recycling rate in Europe 
generally and Hungary specifically. The data showed that Hungary does not have noticeable increase in the recycling rate in the last few years, which reflects a possibility and need for further research and developments in this area. Also, the data showed interesting results from the Slovakian data. A comparison between Hungary and Slovakia was presented that showed a big increase in recycling operations in Slovakia compared to Hungary from 2014 to 2020. Considering the nearby geographical location and relatively similar country area, this study suggests a deeper analysis of the waste management operations in Hungary and Slovakia that can be used and reflected on the waste management system positively in Hungary, Slovakia, or both.

\section{ACKNOWLEDGMENT}

This work is supported by the ÚNKP-21-3 NEW NATIONAL EXCELLENCE PROGRAM OF THE MINISTRY FOR INNOVATION AND TECHNOLOGY FROM THE SOURCE OF THE NATIONAL RESEARCH, DEVELOPMENT AND INNOVATION FUND.

References: 1. Mesjasz-Lech, A., Michelberger. P., Sustainable Waste Logistics and the Development of Trade in Recyclable Raw Materials in Poland and Hungary, Sustainability (2019) https://doi.org/10.3390/su11154159. 2. Proposal for a Directive of the European Parliament and of the Council Amending Directive 94/62/EC on Packaging and Packaging Waste. 2015. Available: https://eurlex.europa.eu/legal-content/EN/TXT/?uri=CELEX:52015PC0596 Accessed: 13/01/2022. 3. Bing, X., Bloemhof, J.M., Ramos, T.R.P., Barbosa-Povoa, A.P., Wong, C.Y., Van Der Vorst, J.G.: Research challenges in municipal solid waste logistics management, Waste Management (2016) pp. 584-592, https://doi.org/10.1016/j.wasman.2015.11.025. 4. Akkad, M.Z., Bányai, T.: Cyber-physical waste collection system: a logistics approach, In: Solutions for Sustainable Development: Proceedings of the 1st International Conference on Engineering Solutions for Sustainable Development (2019) pp.160-168, https://doi.org/10.1201/9780367824037. 5. Straka, M., Rosova, A., Malindzakova, M., Khouri, S., Culkova, $K$.: Evaluating the waste incineration process for sustainable development through modelling, logistics, and simulation, Polish Journal of Environmental Studies (2018) pp. 2739-2748, https://doi.org/10.15244/pjoes/81062. 6. Bing, X., Bloemhof, J.M., Ramos, T.R.P., Barbosa-Povoa, A.P., Wong, C.Y., Van Der Vorst, J.G.: Research challenges in municipal solid waste logistics management, Waste Management (2016) pp. 584-592, https://doi.org/10.1016/j.wasman.2015.11.025. 7. Winkler, H., Kaluza, B.: Sustainable supply chain networks - A new approach for effective waste management, WIT Transactions on Ecology and the Environment, (2006) pp. 501-510 https://doi.org/10.2495/WM060521. 8. Das, S., Lee, S.H., Kumar, P., Kim, K.H., Lee, S.S., Bhattacharya, S.S.: Solid waste management: Scope and the challenge of sustainability, Journal of Cleaner Production, (2019) pp. 658-678 https://doi.org/10.1016/j.jclepro.2019.04.323. 9. Bányai, T., Tamás, P., Illés, B., Stankevičiūtè, Z., Bányai, Á.: Optimization of municipal waste collection routing: impact of industry 4.0 technologies on environmental awareness and sustainability, International Journal of Environmental Research and Public Health (2019) https://doi.org/10.3390/ijerph16040634. 10. Gomes, M.I., Barbosa-Povoa, A.P., Novais, A.Q.: Modelling a recovery network for WEEE: A case study in Portugal, Waste Management (2011) pp. 1645-1660 https://doi.org/10.1016/j.wasman.2011.02.023. 11. MarOrtiz, J., Adenso-Diaz, B., Gonzalez-Velarde, J.L.: Design of a recovery network for WEEE, collection: The case of Galicia, Spain, Journal of the Operational Research Society (2011) pp. 1471-1484 https://doi.org/10.1057/jors.2010.114. 12. Demirel, E., Demirel, N., Gokcen, H.: A mixed integer linear programming model to optimize reverse logistics activities of end-of-life vehicles in Turkey, Journal of Clean 
Production (2016) pp. 2101-2113 https://doi.org/10.1016/j.jclepro.2014.10.079. 13. Chung, S.S., Lau, K.Y., Zhang, C.: Generation of and control measures for e-waste in Hong Kong, Waste Management (2011) pp. 544-554 https://doi.org/10.1016/j.wasman.2010.10.003. 14. Grunow, M., Gobbi, C., Alting, L.: Designing the reverse network for WEEE in Denmark, CIRP Annals (2009) pp. 391-394 https://doi.org/10.1016/j.cirp.2009.03.036. 15. Kinobe, J.R., Bosona, T., Gebresenbet, G., Niwagaba, C.B., Vinneras, B.: Optimization of waste collection and disposal in Kampala city. Habitat International (2015) pp. 126-137 https://doi.org/10.1016/j.habitatint.2015.05.025. 16. Gamberini, R., Gebennini, E., Rimini, B.: An innovative container for WEEE collection and transport: Details and effects following the adoption. Waste Management (2009) pp. 2846-2858 http://dx.doi.org/10.1016/j.wasman.2009.07.006. 17. Yu, M.C., Wu, P.S.: A simulation study of the factors influencing the design of a waste collection channel in Taiwan, International Journal of Logistics Research and Applications (2010) pp. 257-271 https://doi.org/10.1080/13675561003724646. 18. Eurostat Statistics: Municipal waste by waste management operations. Available: https://ec.europa.eu/eurostat/cache/metadata/en/env_wasmun_esms.htm Accessed: 13/01/2022. 19. Eurostat Statistics: Recycling rate of municipal waste. Available: https://ec.europa.eu/eurostat/cache/metadata/en/cei_wm011_esmsip2.htm.

\title{
Мохаммад Захер Аккад, Тамаш Баньяї, Мішкольц, Угорщина
}

\section{АНАЛІЗ І ПОРІВНЯННЯ РОЗВИТКУ УПРАВЛІННЯ ВІДХОДАМИ В УГОРЩИНІ І СЛОВАЧЧИНІ}

\begin{abstract}
Анотація. Виробництво відходів є незмінним людським процесом, що відбувається щодня у всіх спільнотах. $3 i$ зростанням населення та розвитком промисловості, обсяги відходів зростають $i$ прочеси їх переробки займають дедалі більшу частку транспортних та вантажнорозвантажувальних завдань у міській логістичі. Збори, транспортування та обробка відходів описуються як управління відходами, яке було досліджено та розроблено, зокрема, з різними додатками, рішеннями та розробками в галузі логістики, транспорту та промисловості. Крім того, з підвищеною увагою до впливу на навколишне середовище у різних галузях, екологічний аспект управління відходами набуває більшого значення, особливо у міській логістиці, де регулярно виникають затори. В рамках иієї роботи аналізується поводження з відходами в Європі загалом та в Угорщиині зокрема. База даних Євростату використовується для иієї мети поряд із попередньою дослідницькою роботою, присвяченій иій темі. Крім того, обговорюється порівняння операчій з відходами в Угорщині та Словаччині, щоб показати різницю у розвитку цих операцій між двома краӥнами у період з 2014 до 2020 року. Зважаючи на важливість систем поводження з відходами, які мають безпосередній вплив на екологічні, соціальні аспекти та аспекти стійкості, у иій роботі був представлений аналіз річної кількості побутових відходів, що утворюються в кілограмах на душу населення, та річного рівня переробки в Свропі взагалі та Угорщині зокрема. Дані показали, що в Угорщині за останні кілька років не спостерігається помітного збільшення рівня реииркуляиії, що відображає можливість та необхідність подальших досліджень та розробок у иій галузі. Крім того, дослідження показали цікаві результати зі словацьких даних. Було представлено порівняння між Угорщиною та Словаччиною, яке показало значне зростання операцій з переробки відходів у Словаччині порівняно з Угорщиною з 2014 до 2020 року. 3 огляду на близьке географічне розтамування та відносно схожу територію краӥни, це дослідження пропонує більш глибокий аналіз операцій 3 відходами в Угорщині. та Словаччини, які можна використовувати та які можуть позитивно позначитися на системі управління відходами в Угорщині, Словаччині або в обох краӥнах.
\end{abstract}

Ключові слова: керування відходами; міська логістика; аналіз даних. 